\title{
Investigation of the use of Leeb hardness in the estimation of some physical and mechanical properties of rock materials
}

\section{Leeb sertliğinin kaya malzemelerin bazı fiziksel ve mekanik özelliklerinin tahmininde kullanımının araştırılması}

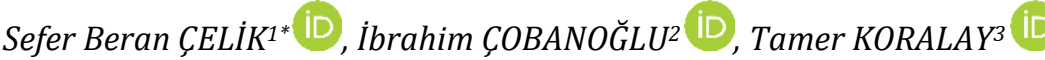 \\ 1,2,3Department of Geological Engineering, Faculty of Engineering, Pamukkale University, Denizli, Turkey. \\ scelik@pau.edu.tr, icobanoglu@pau.edu.tr, tkoralay@pau.edu.tr
}

\section{Abstract}

Uniaxial compressive strength (UCS) and some physical properties of rock materials are very important input parameters used in rock mechanics and engineering. Samples with standard shape and dimension are used in physical and mechanical tests. However, it is difficult to determine the UCS values in case of difficult sample preparation conditions. To overcome this limitation prediction of UCS values from indirect test methods is preferred. One of the most common parameters used to predict the UCS values of rock materials is surface hardness. In this study, the usability of hardness values $\left(H_{L}\right)$ of selected ignimbrite, travertine and syenite rocks in the prediction of some physical and mechanical properties were investigated by using the Leeb hardness test which has much lower impact energy than the Schmidt hardness hammer has. Firstly, petrographic and some physical and mechanical properties of the samples were determined and then the $H_{L}$ measurements of all samples were taken. Test results were correlated and correlation equations for dry $\left(\gamma_{d r y}\right)$ and saturated $\left(\gamma_{\text {sat }}\right)$ unit weights, apparent porosity $\left(n_{A}\right)$, water absorption ( $\left.w S\right)$, sonic wave velocity $\left(V_{P}\right)$ were presented and prediction equation of UCS from $H_{L}$ measurements were proposed. In the context of the study, the effect of $L / D$ ratio on $H_{L}$ measurements were also investigated and minimum length to diameter $(L / D)$ ratio of 1.5 on samples with $50 \mathrm{~mm}$ in diameter was suggested for consistent $H_{L}$ measurements.

Keywords: Ignimbrite, Travertine, Uniaxial compressive strength, Leeb hardness.

\section{Introduction}

The uniaxial compressive strength (UCS) value, used in rock mechanics and engineering projects, is one of the basic parameters of rock materials. Precisely prepared samples are used in the direct determination of UCS values in laboratory conditions, expensive test equipment with precise loading and control systems are also needed. Due to the difficulty of sample preparation and long test times, it is preferable to estimate UCS values indirectly with practical and economical indirect test methods. Furthermore, the use of indirect test methods is very important in estimating the UCS values of weak rock materials such as tuff, claystone and ignimbrite on which sampling and preparation is very difficult. One of the test methods in the prediction of UCS values is the surface hardness values determined by practical and economical test methods.

\section{Öz}

Kaya malzemelerin tek eksenli sıkışma dayanımı (UCS) ve bazı fiziksel özellikleri kaya mekaniği ve mühendisliğinde kullanılan çok önemli girdi parametreleridir. Fiziksel ve mekanik özelliklerin belirlendiği deneylerde, belirli şekil ve boyuttaki standart örnekler kullanılmaktadır. Ancak, örnek hazırlamanın güç olduğu koșullarda bu değerlerin belirlenmesi güçleşmekte ve bu sorunun aşllması amacıyla doğrudan olmayan deney yöntemlerinden tahminleri tercih edilmektedir. Kaya malzemelerin özelliklerinin tahmininde kullanılan en yaygın parametrelerden birisi de yüzey sertliğidir. Bu çalıșma kapsamında kaya malzemeler üzerinde kullanımı yaygınlașmaya başlayan ve Schmidt çekicine göre, çok daha düşük bir çarpma enerjisine sahip olan Leeb sertlik cihazı ile elde edilen sertlik değerlerinin $\left(H_{L}\right)$ seçilen ignimbirit, traverten ve siyenit türü kayaların bazı fiziksel ve mekanik özelliklerinin tahmininde kullanılabilirliği araștırılmıştır. Öncelikle örneklerinin petrografik ve temel fiziksel özellikleri incelenmiș, daha sonra tüm örneklerin $H_{L}$ değerleri ölçülmüştür. Kuru ( $\gamma_{\text {ary }}$ ) ve doygun ( $\gamma_{\text {sat }}$ ) birim hacim ağırlıklar, görünür porozite $\left(n_{A}\right)$, su emme $\left(w_{S}\right)$, ultrases hızı $\left(V_{P}\right)$ değerleri ile $H_{L}$ değerleri korele edilmiș ve ilgili eșitliklerle sunulmustur ayrıca $H_{L}$ değerlerinden UCS değerlerinin tahmini için bir eşitlik önerilmiştir. Çalış̧ma kapsamında, örneklerin boy/çap oranının (L/D) $H_{L}$ ölçümleri üzerine etkisi de araştırılmıştır. Sonuç olarak $50 \mathrm{~mm}$ çaplı ve minimum $1.5 \mathrm{~L} / \mathrm{D}$ oranlı örnekler üzerinde $H_{L}$ değerlerinin sağlıklı olarak ölçülebileceği önerilmiştir.

Anahtar kelimeler: İgnimbirit, Traverten, Tek eksenli sıkışma dayanımı, Leeb sertliği.

Hardness is an important feature of rock-forming minerals and is a measure of scratching or abrading resistance of a mineral surface. Considering that the rock materials consist of minerals having hardness values vary from low to high controls the hardness value of overall rock. The hardness value of rocks is one of the important material properties for various engineering projects. Schmidt hammer hardness is the most widely used test method for determining the hardness values of rock materials. This test was initially proposed to determine the quality of concrete as a non-destructive test method and has been used for many years [1]. It is possible to come across many studies on the prediction of UCS values of rocks from Schmidt hardness values [2]-[4]. The Schmidt hammer is particularly limited in use on weak rock materials. Depending on the impact energy applied by the hammer, it is encountered that the samples can be broken down during the experiment [5]. 
Considering the rock types used in this study, the presence of ignimbrite as a weak rock material made it impossible to perform Schmidt hardness tests. For the purpose and subject of the study, the Leeb hardness test which has a much lower impact energy and a more sensitive test method than Schmidt hammer was used. The Leeb hardness test method was developed in the 1970s for the measurement of hardness of metallic materials [6]. This method is known as a fast and economical test method which can be used in various directions in a wide range of its hardness scale [7]. Leeb hardness value $\left(\mathrm{H}_{\mathrm{L}}\right)$ ranges from 170 to 960 , with rising values indicating materials with higher surface hardness. There are studies on the prediction of uniaxial compression strength from $\mathrm{H}_{\mathrm{L}}$ values [8]-[17]. In addition, the relationship between discontinuity wall strength and surface hardness was examined [18], rock hardness and surface hardness changes were examined [19],[20], time dependent changes of surface hardness values of concrete and some rocks were monitored [21] and the relationship between hardness values and rock cuttability was investigated [22].

In this study, rock samples prepared from syenite and two types of ignimbrite and travertine were used. The relationships between the obtained experimental data were investigated and the equations were presented. The scope of this study is to estimate the UCS values from Leeb hardness values of rock materials. In this context, it is aimed to propose equations for the estimation of the UCS values of rocks from the $\mathrm{H}_{\mathrm{L}}$ values which are measured practically and economically. In addition, the effect of different $\mathrm{L} / \mathrm{D}$ ratios of core samples on $\mathrm{H}_{\mathrm{L}}$ values were investigated.

\section{Materials and methods}

Five groups of rocks were investigated. According to ISRM [23], NX diameter core samples were extracted from the blocks brought to the laboratory, the upper and lower surfaces were grinded and a total of 45 samples were prepared (Figure 1). All experimental studies were carried out in Rock Mechanics laboratory of Pamukkale University.

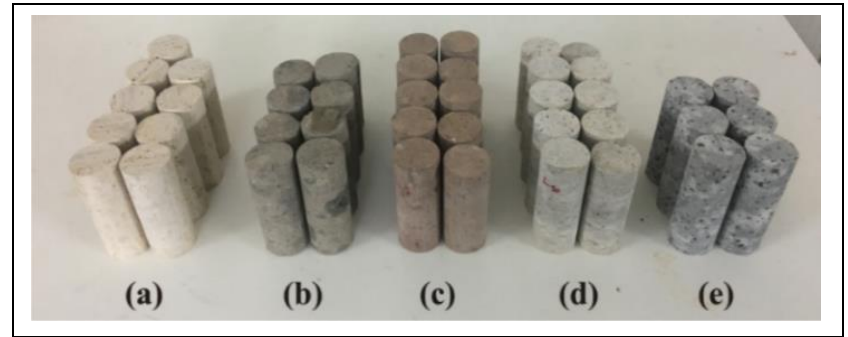

Figure 1. Views of core samples used in this study.

(a): Travertine-1, (b): Ignimbrite-1, (c): Ignimbrite-2, (d): Travertine-2, (e): Syenite).

Thin sections were prepared and petrographic examinations were performed. Macroscopic views, thin section views, petrographic descriptions and mohs hardness evaluations of sample groups were given in Table 1.

Dry and saturated unit volume weights $\left(\gamma_{\mathrm{dry}}, \gamma_{\mathrm{sat}}\right)$, apparent porosity $\left(\mathrm{n}_{\mathrm{A}}\right)$, water absorption $\left(\mathrm{w}_{\mathrm{s}}\right)$, ultrasonic wave velocity $\left(V_{P}\right)$ and uniaxial compressive strength (UCS) parameters of all samples were determined. Leeb hardness $\left(\mathrm{H}_{\mathrm{L}}\right)$ of all samples was measured before UCS tests. The correlations between hardness values and other parameters were investigated and related equations were presented.
In theory, hardness is a property of minerals rather than rocks. Similarly, the alteration of these minerals, which are forming the rock, significantly affects the hardness of the rock. In this sense, it can be concluded that the Mohs hardness values of the studied T-1 and T-2 travertine samples are between 3-4, I-1 and I-2 ignimbrite samples are between 4.5-5.5 and S-1 nepheline syenite sample group is between 6-6.5.

\section{Physical and mechanical properties}

\subsection{Physical properties}

$\gamma_{\text {dry }}, \gamma_{\mathrm{sat}}, \mathrm{n}_{\mathrm{A}}$ and $\mathrm{w}_{\mathrm{s}}$ values as basic physical properties were determined on the prepared core samples. The experiments were conducted according to ISRM [23]. According to the results, the lowest mean $\gamma_{\mathrm{k}}$ value was $11.27 \mathrm{kN} / \mathrm{m}^{3}$ and the highest value was $24.56 \mathrm{kN} / \mathrm{m}^{3}$ were determined for ignimbrite (I-1) and syenite (S-1) groups respectively. The average apparent porosity values were obtained as 0.49 and $36.19 \%$ for S-1 and I-1 groups respectively. $\mathrm{n}_{\mathrm{A}}$ values of the studied rock groups were found vary in a wide range and the lowest $\mathrm{w}_{\mathrm{s}}$ values were obtained for S-1 and the highest values were found for I-1 group in parallel with the apparent porosity values. The longitudinal wave velocities were measured using the Proceq $\mathrm{Lab}+$ tester. $\mathrm{V}_{\mathrm{P}}$ velocities were obtained for travertine (T-2) group with the highest value of $5.330 \mathrm{~km} / \mathrm{h}$ and the lowest velocity values were obtained for ignimbrite (I-1) groups with the average value of $1.876 \mathrm{~km} / \mathrm{h}$. Studying on samples having wide range of physical and mechanical properties, allows to get statistically strong correlations. The obtained results as minimum, maximum, average and standard deviation values for each group were given in Table 2 .

\subsection{Uniaxial compressive strength test results}

UCS tests were carried out on cored samples which were extracted from block samples, having $54 \mathrm{~mm}$ diameter and L/D ratio of 2.5. UCS test system with $2000 \mathrm{kN}$ loading capacity was used in the tests. It was determined that the average UCS values of the studied samples ranged from 5.79 to $117.56 \mathrm{MPa}$. According to ISRM [23], when the average UCS values of two types of ignimbrites are taken into consideration, these groups are in "weak" and "medium strength rock groups, while travertines are in "medium strength", rock group and the syenite group is in "very strong rock" group. Minimum, maximum, average and standard deviation values of UCS test results of all groups were given in Table 2. In UCS tests layered structure especially for the travertines were not observed. For this reason, test conditions related to layered structure for the samples were not considered.

\section{Determination of Leeb hardness values}

Leeb hardness values of the studied rock groups were measured by TIME $^{\circledR} 5100$ pocket size battery operated hardness device. Initially, the Leeb hardness was proposed to obtain the hardness values of metal products. However, the method has been widely using on rock materials as nondestructive, economical, and practical hardness measurements [8]-[17].

Although there are devices manufactured by different companies, their operating principle is the same. Hardness is calculated by the ratio between the measured impact and rebound velocities of the tip when it is $1 \mathrm{~mm}$ far from the material surface. The hardness value is determined by the equation given below (Eq. 1). 


$$
H_{L}=\frac{V_{\text {rebound }}}{V_{\text {impact }}} \times 1000
$$

Where; $H_{L}$ : Leeb hardness value, $V_{\text {rebound }}$ : Rebounding velocity of the tip, $V_{\text {impact }}$ : Impacting velocity of the tip [6].
Leeb hardness devices having different impact energies have been using, hardness devices with type " $D$ " impact mechanism is commonly used. The device used in this study includes the type " $\mathrm{D}$ " impact mechanism. The tip weight is $5.5 \mathrm{~g}$ and it applies $11 \mathrm{Nmm}$ impact energy. It is seen that the impact energy is significantly lower compared to the widely used L-type Schmidt hardness hammer.

Table 1. Minero-petrographic investigations of sample groups.

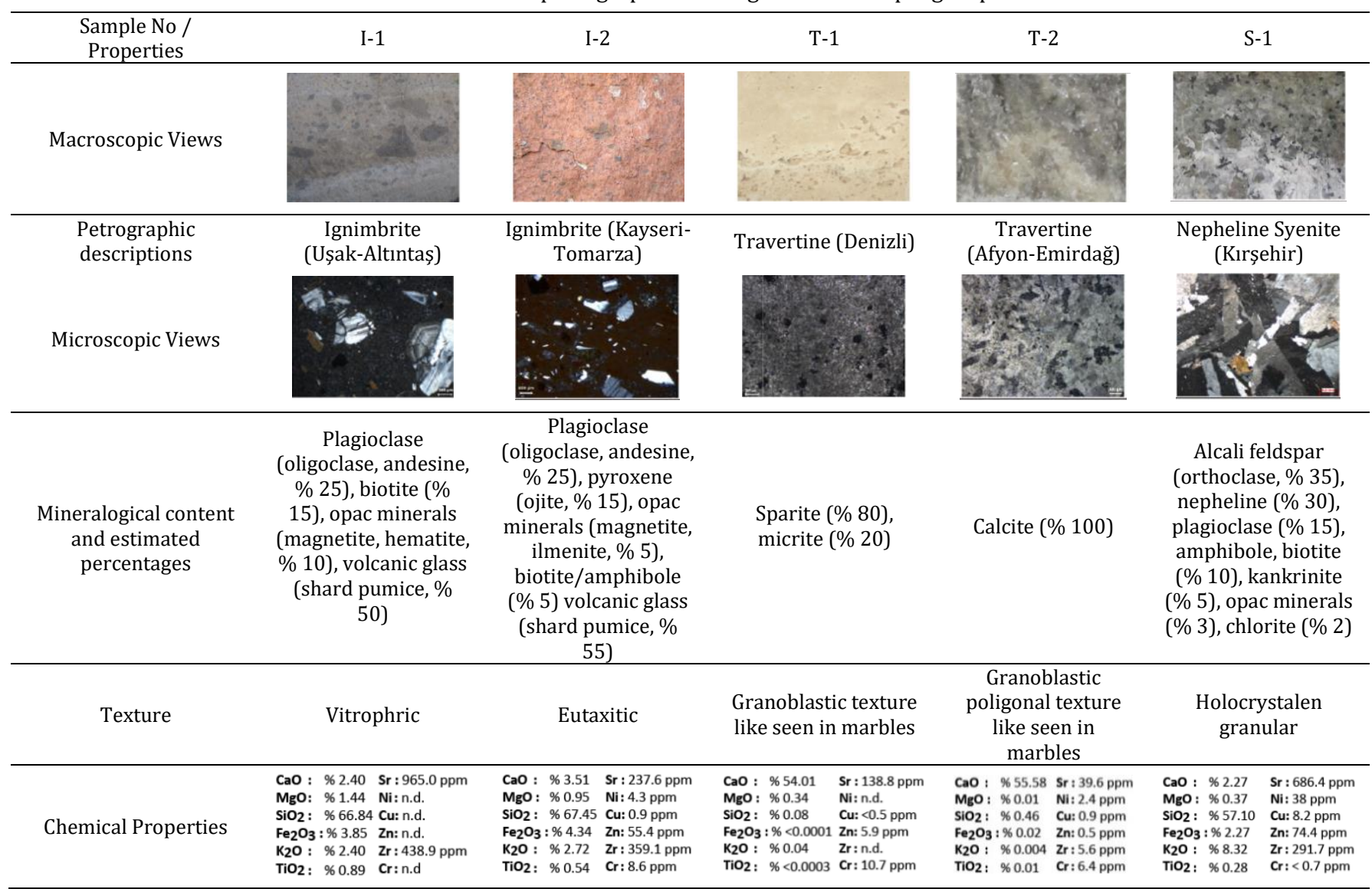

Table 2. Obtained test results.

\begin{tabular}{|c|c|c|c|c|c|c|c|}
\hline San & & $\begin{array}{c}\gamma_{\text {dry }} \\
\left(\mathrm{kN} / \mathrm{m}^{3}\right)\end{array}$ & $\begin{array}{c}\gamma_{\mathrm{sat}} \\
\left(\mathrm{kN} / \mathrm{m}^{3}\right)\end{array}$ & $\begin{array}{c}\mathrm{n}_{\mathrm{A}} \\
(\%) \\
\end{array}$ & $\begin{array}{c}\mathrm{W}_{\mathrm{s}} \\
\% \\
\end{array}$ & $\begin{array}{c}\mathrm{V}_{\mathrm{P}} \\
(\mathrm{km} / \mathrm{s})\end{array}$ & $\begin{array}{c}\text { UCS } \\
(\mathrm{MPa})\end{array}$ \\
\hline \multirow{4}{*}{ I-1 } & Min & 10.59 & 14.38 & 34.51 & 28.65 & 1.745 & 4.03 \\
\hline & Max & 11.81 & 15.20 & 38.68 & 35.83 & 2.079 & 7.01 \\
\hline & $A v$ & 11.27 & 14.82 & 36.19 & 31.54 & 1.876 & 5.79 \\
\hline & Std. D. & 0.33 & 0.26 & 1.13 & 1.84 & 0.113 & 0.95 \\
\hline \multirow{3}{*}{$\mathrm{I}-2$} & Min & 15.97 & 19.34 & 25.71 & 14.54 & 2.68 & 24.61 \\
\hline & Max & 17.53 & 20.13 & 41.40 & 25.42 & 2.87 & 44.72 \\
\hline & Std. D. & 0.47 & 0.23 & 4.46 & 3.13 & 0.07 & 5.54 \\
\hline \multirow{4}{*}{ T-1 } & Min & 21.52 & 22.34 & 7.57 & 3.35 & 5.06 & 30.34 \\
\hline & Max & 22.28 & 23.05 & 8.82 & 3.93 & 5.24 & 62.88 \\
\hline & $A v$ & 22.06 & 22.87 & 8.17 & 3.63 & 5.15 & 46.45 \\
\hline & Std. D. & 0.22 & 0.20 & 0.38 & 0.19 & 0.05 & 10.80 \\
\hline \multirow{3}{*}{ T-2 } & Min & 23.19 & 23.82 & 2.35 & 0.97 & 4.90 & 27.75 \\
\hline & Max & 24.07 & 24.35 & 7.29 & 3.08 & 5.59 & 53.65 \\
\hline & $A v$ & 23.77 & 24.11 & 3.38 & 1.40 & 5.33 & 42.51 \\
\hline \multirow{4}{*}{ S-1 } & Min & 24.01 & 24.06 & 0.41 & 0.16 & 4.60 & 94.04 \\
\hline & Max & 25.02 & 25.07 & 0.53 & 0.21 & 4.95 & 131.28 \\
\hline & $A v$ & 24.56 & 24.61 & 0.49 & 0.20 & 4.80 & 117.56 \\
\hline & Std. D. & 0.32 & 0.32 & 0.04 & 0.02 & 0.10 & 13.40 \\
\hline
\end{tabular}


The Leeb and Schmidt hardness devices have impact values of 11 and $735 \mathrm{Nmm}$ respectively, and the Leeb hardness device has impact energy of about 66 times lower than the Schmidt hammer. In this respect, the Leeb hardness test is particularly useful for weak rock materials and stands out as a more nondestructive hardness test.

A standard test procedure for the determination of $\mathrm{H}_{\mathrm{L}}$ values has not yet been proposed by organizations known as ISRM, ASTM. Different researchers have used different test methods. These methods can be divided into two groups; The first is the average of the measured values taken at various spots on the rock sample, and the second is the average of the repeated measurements taken at the same point. It is clear that rock materials are composed of different minerals and the measurements taken at a single point will vary depending on the location of the point where the measurement is taken.

In addition, repeated measurement at the same point will result in different values at different points due to the rebound behavior beginning with elastic and then returning to a plastic behavior due to disturbance. In this study, the average of 20 measurements was taken as $\mathrm{H}_{\mathrm{L}}$ value. As shown in Figure 2, the measurements were taken on 4 line along the long axis which are equally spaced and parallel to each other of each core sample with L/D ratio of 2.5. Equally spaced 5 measurements in each line were measured.

20 hardness measurements were taken at different points on 45 samples. All measurements were taken in holding the device in vertical position. The minimum, maximum, average and standard deviation values obtained for each sample were given in Table 3. When the hardness values were examined, the lowest hardness value was measured as 221 for the ignimbrite group (I-1) and the highest hardness value was obtained as 840 for the syenite group (S-1)

It is seen that the obtained $\mathrm{H}_{\mathrm{L}}$ values differ in ignimbrite and travertine samples represented by two groups.

It can be said that this difference is related to different welding degree of ignimbrite samples and the differences seen on travertines is related to the differences in textural properties. Sparite composition is dominant in $\mathrm{T}-1$ group travertines, however, the presence of coarser calcite minerals in $\mathrm{T}-2$ group was observed, thus lower hardness values for T-1 group were obtained compared to T-2 group. The highest $\mathrm{H}_{\mathrm{L}}$ values were obtained for the nepheline syenite group in relation to the hardness of alkali feldspar, nepheline and plagioclase minerals.

\subsection{Evaluation of sample size on hardness measurement}

In this study, the variation of $\mathrm{H}_{\mathrm{L}}$ hardness values with sample size was also investigated. There were studies on the variations of hardness values with sample size.

Verwaal and Mulder [8] suggested that there was little change in hardness measurements on samples thicker than $50 \mathrm{~mm}$. Similar results were also proposed by Kawasaki et al. [10]. Corkum et al. [17] suggested that $\mathrm{H}_{\mathrm{L}}$ hardness measurements can be taken on samples with minimum volume of $90 \mathrm{~cm}^{3}$. Güneş Yılmaz [13] stated that $\mathrm{H}_{\mathrm{L}}$ values can be determined on samples minimum $54 \mathrm{~mm}$ in diameter. To investigate the variation of hardness values, samples with $54 \mathrm{~mm}$ in diameter and $25,50,75,100$ and $125 \mathrm{~mm}$ in length were prepared (Figure 2b) and the hardness values of the samples were obtained. In order to determine the effect of L/D ratios on $\mathrm{H}_{\mathrm{L}}$ measurements average of 20 measurements were taken on each sample with different $L / D$ ratios. The measurements were taken on both axis and end surfaces of each sample.

Table 3. $H_{L}$ measurement results.

\begin{tabular}{|c|c|c|c|c|c|c|c|c|c|}
\hline No & Min & Max & $A v$. & Std.D. & No & Min & Max & $A v$. & Std.D. \\
\hline S1-1 & 785 & 899 & 848.65 & 32 & I2-8 & 337 & 721 & 513.55 & 88 \\
\hline S1-2 & 769 & 898 & 840.2 & 39 & I2-9 & 323 & 687 & 538.5 & 98 \\
\hline S1-3 & 785 & 923 & 857.75 & 43 & $\mathrm{I} 2-10$ & 364 & 650 & 521.55 & 79 \\
\hline S1-4 & 748 & 894 & 836.6 & 39 & $\mathrm{~T} 1-1$ & 405 & 665 & 555.45 & 83 \\
\hline S1-5 & 751 & 892 & 838.45 & 43 & T1-2 & 226 & 626 & 441.7 & 80 \\
\hline S1-6 & 766 & 879 & 838.3 & 32 & $\mathrm{~T} 1-3$ & 176 & 637 & 502.05 & 128 \\
\hline S1-7 & 688 & 903 & 820.5 & 51 & T1-4 & 245 & 665 & 501.95 & 127 \\
\hline I1-1 & 189 & 282 & 228.15 & 22 & T1-5 & 271 & 665 & 527.6 & 93 \\
\hline $\mathrm{I} 1-2$ & 192 & 276 & 221.85 & 22 & T1-6 & 388 & 617 & 541.65 & 64 \\
\hline I1-3 & 179 & 230 & 204.25 & 12 & T1-7 & 206 & 670 & 494.35 & 139 \\
\hline I1-4 & 175 & 271 & 217.3 & 29 & T1-8 & 210 & 632 & 472.95 & 104 \\
\hline I1-5 & 178 & 254 & 223.45 & 20 & T1-9 & 340 & 655 & 530.1 & 87 \\
\hline I1-6 & 194 & 260 & 222 & 17 & $\mathrm{~T} 2-1$ & 486 & 631 & 572.95 & 40 \\
\hline $\mathrm{I} 1-7$ & 188 & 280 & 237.3 & 27 & $\mathrm{~T} 2-2$ & 331 & 640 & 525.5 & 77 \\
\hline I1-8 & 181 & 245 & 213.05 & 16 & $\mathrm{~T} 2-3$ & 355 & 634 & 559.1 & 79 \\
\hline I1-9 & 175 & 274 & 220.55 & 24 & $\mathrm{~T} 2-4$ & 251 & 616 & 516.85 & 87 \\
\hline I2-1 & 289 & 641 & 515.5 & 85 & $\mathrm{~T} 2-5$ & 454 & 657 & 584.2 & 47 \\
\hline $\mathrm{I} 2-2$ & 338 & 616 & 507.55 & 61 & T2-6 & 483 & 645 & 589.8 & 41 \\
\hline I2-3 & 408 & 680 & 536.25 & 71 & $\mathrm{~T} 2-7$ & 401 & 646 & 575.55 & 53 \\
\hline I2-4 & 352 & 682 & 516.35 & 81 & $\mathrm{~T} 2-8$ & 421 & 624 & 541.3 & 48 \\
\hline I2-5 & 363 & 710 & 546.8 & 81 & T2-9 & 525 & 646 & 594 & 35 \\
\hline I2-6 & 350 & 586 & 501.2 & 61 & $\mathrm{~T} 2-10$ & 364 & 641 & 561.4 & 67 \\
\hline I2-7 & 340 & 688 & 518.2 & 78 & --- & --- & --- & --- & --- \\
\hline
\end{tabular}



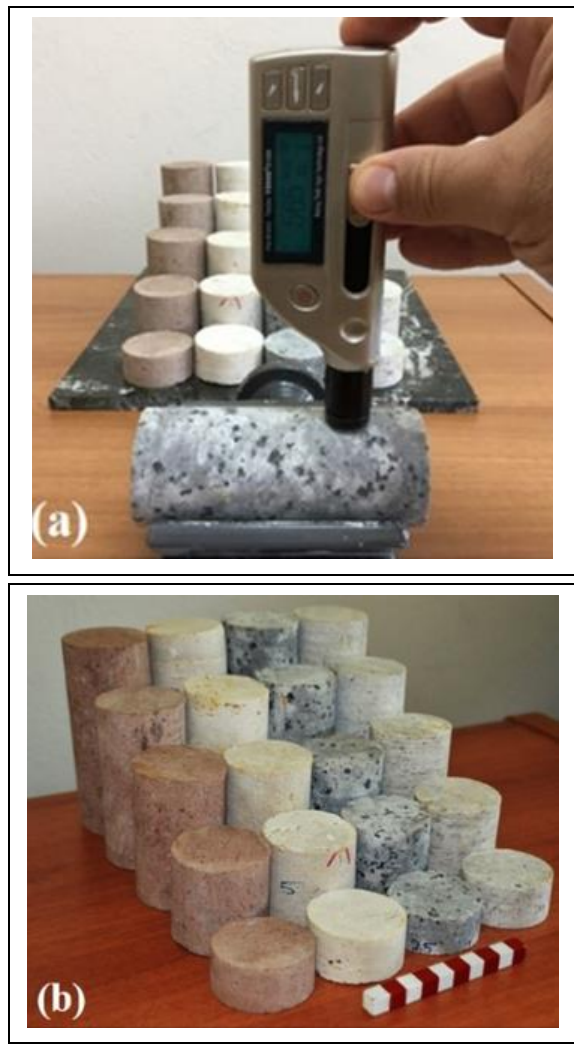

Figure 2. Hardness measurement by portable Leeb hardness tester. (a): and prepared samples for the evaluation of size effect (b).

There are studies especially on the variation of strength of core samples with different L/D ratios [24-27]. The effect of the sample size on the measured hardness values was investigated on the samples with different L/D ratios. In Figure 3. Variations of hardness values with increasing $\mathrm{L} / \mathrm{D}$ ratios were given. It was observed that critical L/D ratio for syenite (Figure 3a), travertine-1 (Figure 3b), ignimbrite-2 (Figure 3c) and travertine-2 (Figure $3 \mathrm{~d}$ ) sample groups is found to be 1.5. It was determined that the measured hardness values above this limit L/D ratio, are close to each other. In Figure 3, power functions are given for modeling the increasing of hardness values. Samples with a L/D ratio of 1.5 correspond to approximately $110 \mathrm{~cm}^{3}$ of volume, and it has been observed that this volume should be regarded as the minimum sample volume for the measurement of $\mathrm{H}_{\mathrm{L}}$ values without sample size effect.

\section{Correlations of test results with hardness values}

Through the main purpose of this study, $\mathrm{H}_{\mathrm{L}}$ values which can be obtained practically by using portable hardness device were correlated with dry unit volume weight $\left(\gamma_{\text {dry }}\right)$, saturated unit volume weight $\left(\gamma_{\text {sat }}\right)$, apparent porosity $\left(\mathrm{n}_{\mathrm{A}}\right)$, water absorption by weight ( $\left.\mathrm{wS}_{\mathrm{S}}\right)$, longitudinal wave velocity $\left(\mathrm{V}_{\mathrm{P}}\right)$ and uniaxial compressive strength (UCS) values of five groups of rocks.

Correlations between $\mathrm{H}_{\mathrm{L}}-\gamma_{\mathrm{dry}}, \mathrm{H}_{\mathrm{L}}-\gamma_{\mathrm{Sat}}, \mathrm{H}_{\mathrm{L}}-\mathrm{V}_{\mathrm{P}}$ and UCS- $\mathrm{H}_{\mathrm{L}}$ are found as power functions, whereas logarithmic functions are obtained for the correlations of $\mathrm{H}_{\mathrm{L}}-\mathrm{n}_{\mathrm{A}}$ and $\mathrm{H}_{\mathrm{L}}$-Ws. The plots of correlations are given in Figure 4a-e. Correlation equations were given in Eq. 2-7.
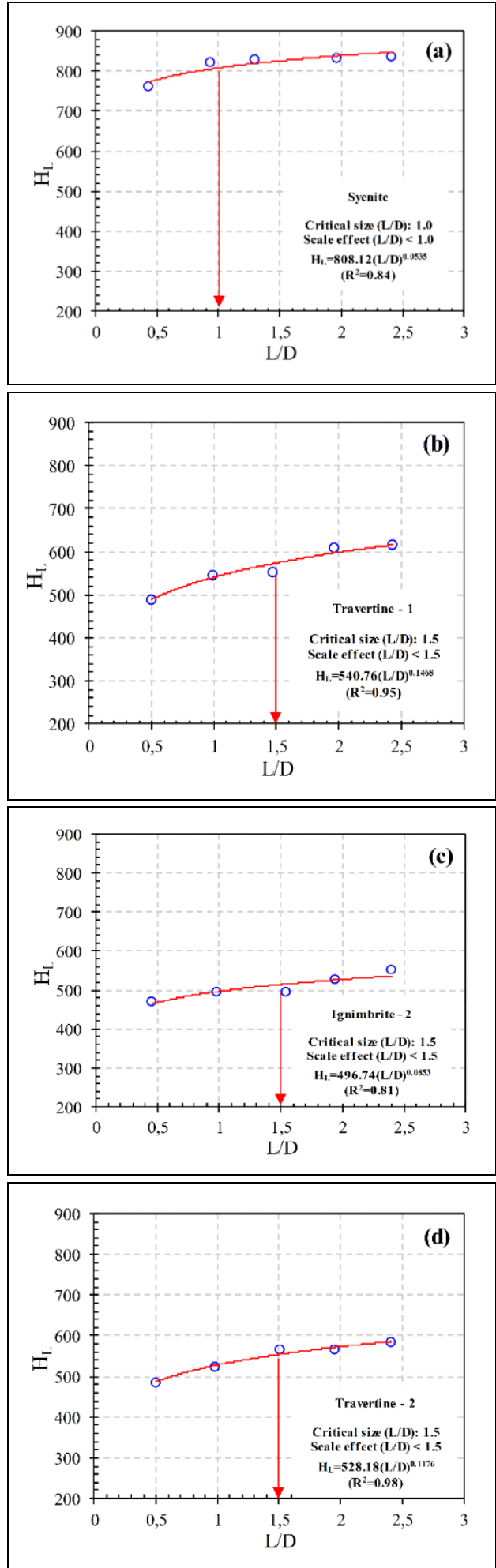

Figure 3. Variations of $\mathrm{H}_{\mathrm{L}}$ measurements with increasing L/D ratio.

The minimum coefficient of determination was found between $\mathrm{H}_{\mathrm{L}}-\mathrm{V}_{\mathrm{P}}$ as 0.63 (Figure $4 \mathrm{e}$ ). In fact, hardness is related to the surface properties of a material. The correlation between $\mathrm{H}_{\mathrm{L}}$ and UCS which is one of the most common rock properties was presented in Figure 4f. 


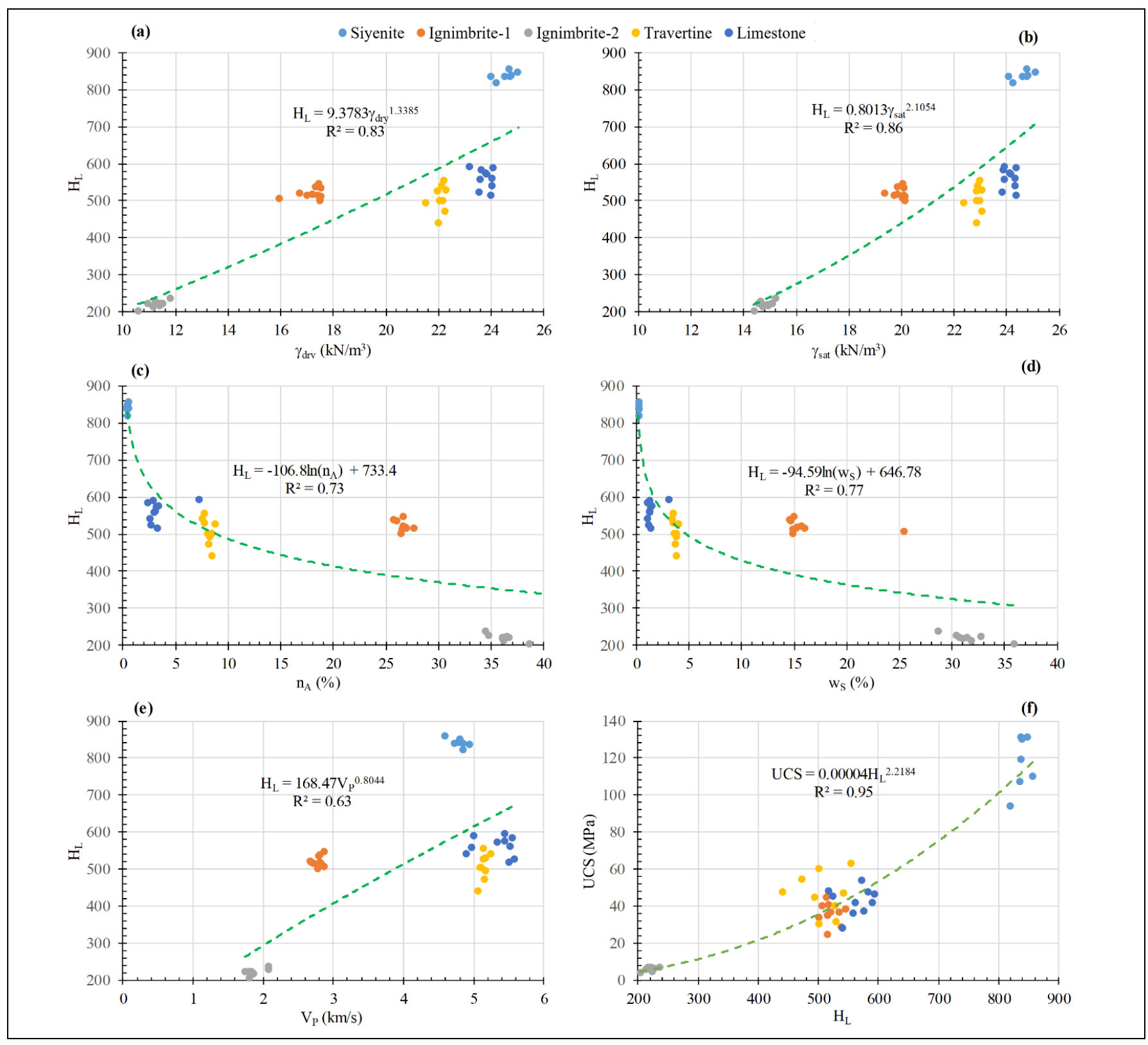

Figure 4. Correlations of $\mathrm{H}_{\mathrm{L}}$ values with other rock properties.

This correlation was proposed with a very high determination coefficient as 0.95 , showed that the UCS values from the $\mathrm{H}_{\mathrm{L}}$ values had good prediction performance for the current data group. When the distribution of UCS and $\mathrm{H}_{\mathrm{L}}$ values were examined, it is observed that the UCS and $\mathrm{H}_{\mathrm{L}}$ values of the T-1, T-2 and I- 1 groups were determined to be close to each other and the data were concentrated in a certain range. In the context of the study, Eq. 7 is proposed for the prediction of UCS values from $H_{L}$ values.

$$
\begin{gathered}
H_{L}=9.3783 \times \gamma_{d r y}^{1.3385}\left(\mathrm{R}^{2}=0.83\right) \\
H_{L}=0.8013 \times \gamma_{\text {sat }}^{2.1054}\left(\mathrm{R}^{2}=0.86\right) \\
H_{L}=-106.8 \times \ln \left(\mathrm{n}_{A}\right)+733.4\left(\mathrm{R}^{2}=0.73\right)
\end{gathered}
$$

$$
\begin{gathered}
H_{L}=-94.59 \times \ln \left(\mathrm{w}_{S}\right)+646.78\left(\mathrm{R}^{2}=0.77\right) \\
H_{L}=168.47 \times V_{P}^{0.8044}\left(\mathrm{R}^{2}=0.63\right) \\
U C S=0.00004 \times H_{L}^{2.2184}\left(\mathrm{R}^{2}=0.95\right)
\end{gathered}
$$

\section{Conclusions}

In this study, the usability of Leeb hardness values in the prediction of UCS parameter of rocks was investigated and correlations of $H_{L}$ values with $\gamma_{\mathrm{dry}}, \gamma_{\mathrm{sat}}, \mathrm{n}_{\mathrm{A}}$, ws and $V_{\mathrm{P}}$ parameters were presented. By using the portable Leeb hardness tester, the hardness of rock materials can be determined very quickly, practically and precisely. All of its advantages makes the method become widespread in engineering purposes. 
Five rock groups including Nepheline syenite, two types of ignimbrite and travertine were studied and correlation equations determined with high determination coefficients were proposed. It was concluded that Leeb hardness values which are the subject of the study differ for the same type of rock materials, the reason was evaluated as the differences in mineralogical, textural and chemical properties of the rocks with the same petrographic descriptions. In the light of the findings of this study, the use of the Leeb hardness test in experimental rock mechanics for different purposes is recommended, especially on weak rocks.

In this study effect of different $\mathrm{L} / \mathrm{D}$ ratios of core samples on $\mathrm{H}_{\mathrm{L}}$ measurements was also investigated. Critical L/D ratio for all samples was obtained as 1.5. This ratio is corresponding to 110 $\mathrm{cm}^{3}$ sample volume. Measured hardness values above this limit are close to each other. As a result of this study, it is suggested that reliable measurements can be taken on samples with 50 $\mathrm{mm}$ in radius with a minimum $\mathrm{L} / \mathrm{D}$ ratio of 1.5 and a minimum volume of $110 \mathrm{~cm}^{3}$.

\section{Acknowledgement}

The hardness test device used in this study was provided within the frame of a project entitled 2018KRM002-392 supported by PAU-BAP. The authors would like to thank the unit for this support. The authors would like to express their sincere gratitude to the anonymous reviewers for their valuable contribution and suggestions.

\section{References}

[1] Hucka V. "A rapid method of determining the strength of rocks in situ". International Journal of Rock Mechanics and Mining Sciences \& Geomechanics Abstracts, 2, 127-134, 1965.

[2] Shalabi FI, Cording EJ, Al-Hattamleh OH. "Estimation of rock engineering properties using hardness tests". Engineering Geology, 90(3), 138-147, 2007.

[3] Karakul H. "Investigation of saturation effect on the relationship between compressive strength and Schmidt hammer rebound". Bulletin of Engineering Geology and the Environment, 76, 1143-1152, 2007.

[4] Demirdağ S, Şengün N, Uğur İ, Altındağ R. "Estimating the uniaxial compressive strength of rocks with Schmidt rebound hardness by considering the sample size". Arabian Journal of Geosciences, 11(502), 1-8, 2018.

[5] Çelik SB, Çobanoğlu İ. "Comparative investigation of shore, schmidt, and Leeb hardness tests in the characterization of rock materials". Environmental Earth Sciences, 78(554), 1-16, 2019.

[6] Leeb D. "Dynamic hardness testing of metallic materials". Non Destructive Testing International, 12(6), 274-278, 1979.

[7] Kompatscher M. "Equotip-rebound hardness testing after D. Leeb”. HARDMEKO 2004 Conference on Hardness Measurements Theory and Application in Laboratories and Industries, Washington, USA, 11-12 November 2004.

[8] Verwaal W, Mulder A, "Estimating rock strength with the Equotip hardness tester". International Journal of Rock Mechanics and Mining Sciences \& Geomechanics Abstracts, 30(6), 659-662, 1993.
[9] Meulenkamp F, Grima MA. "Application of neural networks for the prediction of the unconfined compressive strength (UCS) from Equotip hardness". International Journal of Rock Mechanics and Mining Sciences, 36 (1), 29-39, 1999.

[10] Kawasaki S, Tanimoto C, Koizumi K, Ishikawa M. “An attempt to estimate mechanical properties of rocks using the Equotip hardness tester". Journal of the Japanese Society of Engineering Geology, 43(4), 244-248, 2002.

[11] Aoki H, Matsukura Y. "Estimating the unconfined compressive strength of intact rocks from Equotip hardness". Bulletin of Engineering Geology and the Environment, 67 (1), 23-29, 2008.

[12] Daniels G, McPhe CA, Sorrentino YC, McCurdy P. "Nondestructive strength index testing applications for sand failure evaluation". SPE Asia Pacific Oil and Gas Conference and Exhibition, Perth, Australia, 22-24 October 2002.

[13] Güneş Yılmaz N. "The influence of testing procedures on uniaxial compressive strength prediction of carbonate rocks from Equotip hardness tester (EHT) and proposal of a new testing methodology: Hybrid dynamic hardness (HDH)". Rock Mechanics and Rock Engineering, 46(1), 95-106, 2013.

[14] Lee JS, Smallwood L, Morgan E. "New application of rebound hardness numbers to generate logging of unconfined compressive strength in laminated shale formations". 48th US Rock Mechanics-Geomechanics Symposium, Minneapolis, MN, USA, 1-4 June 2014.

[15] Su 0, Momayez M. "Correlation between Equotip hardness index, mechanical properties and drillability of rocks". Dokuz Eylul University Journal of Science and Engineering, 19 (56), 519-531, 2017.

[16] Güneş Yılmaz N, Göktan RM. "Comparison and combination of two NDT methods with implications for compressive strength evaluation of selected masonry and building stones". Bulletin of Engineering Geology and the Environment, 78, 4493-4503, 2019.

[17] Corkum AG, Asiri Y, El Naggar H, Kinakin D. "The Leeb hardness test for rock: An updated methodology and UCS correlation". Rock Mechanics and Rock Engineering, 51, 665-675, 2018.

[18] Hack HR, Hingira J, Verwaal W. "Determination of discontinuity wall strength by Equotip and ball rebound tests". International Journal of Rock Mechanics and Mining Sciences \& Geomechanics Abstracts, 30(2), 151-155, 1993.

[19] Viles H, Goudie A, Grab S, Lalley J. "The use of the Schmidt Hammer and Equotip for rock hardness assessment in geomorphology and heritage science: a comparative analysis". Earth Surface Processes and Landforms, 36(3), 320-333, 2011.

[20] Mol L. Measuring rock hardness in the field. Editors: Nield J and Clarke L. Geomorphological Techniques. 1-8, UK, British Society for Geomorphology, 2014.

[21] Coombes MA, Feal-Pérez A, Naylor LA, Wilhelm K. "A nondestructive tool for detecting changes in the hardness of engineering materials: Application of the Equotip durometer in the coastal zone". Engineering Geology, 167, 14-19, 2013. 
[22] Güneş Yılmaz N, Tumaç D, Göktan RM. "Rock cuttability assessment using the concept of hybrid dynamic hardness (HDH)". Bulletin of Engineering Geology and the Environment, 74, 1363-1374, 2015.

[23] ISRM. The Complete ISRM Suggested Methods for Rock Characterization, Testing and Monitoring: 1974-2006. Suggested Methods Prepared by the Commission on Testing Methods. Eds: Ulusay R, Hudson JA. Ankara, Turkey, 2007.

[24] Hoek E, Brown ET. Underground excavations in Rock. $1^{\text {st }}$ ed. UK, CRC Press, 1980.
[25] Hawkins AB. "Aspects of rock strength". Bull Eng Geol Environ, 57, 17-30, 1998.

[26] Özkan İ, Özarslan A, Geniş M, Özșen H. "Assessment of scale effects on uniaxial compressive strength in rock salt". Environmental \& Engineering Geoscience, 15(2), 91-100, 2009.

[27] Tuncay E, Hasançebi N. "The effect of length to diameter ratio of test specimens on the uniaxial compressive strength of rock". Bulletin of Engineering Geology and the Environment, 68, 491-497, 2009. 